\title{
Fe modulates Cd-induced oxidative stress and the expression of stress responsive proteins in the nodules of Vigna radiata
}

\author{
Sowbiya Muneer • Tae Hwan Kim • \\ M. Irfan Qureshi
}

Received: 2 April 2012/Accepted: 11 July 2012/Published online: 21 July 2012

(C) The Author(s) 2012. This article is published with open access at Springerlink.com

\begin{abstract}
The aim of this study was to investigate the protective role of $\mathrm{Fe}$ in providing tolerance against $\mathrm{Cd}$-stress in root nodules of Vigna radiata, because $\mathrm{Cd}$ may be more deleterious in the absence of Fe. Biochemical, histological and proteomic responses to $\mathrm{Cd}$-exposure $\left(50 \mu \mathrm{M} \mathrm{CdCl}_{2}\right)$ were examined under Fe-sufficient $(+\mathrm{Fe} /$ $+\mathrm{Cd})$ or $\mathrm{Fe}$-deficient $(-\mathrm{Fe} /+\mathrm{Cd})$ soils by comparing non $-\mathrm{Cd}$ exposed control $(+\mathrm{Fe} /-\mathrm{Cd})$ plants with additional control of $\mathrm{Fe}$-deficient and non-exposed $\mathrm{Cd}$ plants $(-\mathrm{Fe} /$ $-\mathrm{Cd})$. Cd-exposure negatively affected on growth and some physiological parameters of host plant and nodules, and also induced oxidative stress with the decline of antioxidative enzyme activities. The negative effects of $\mathrm{Cd}$-exposure in $+\mathrm{Fe} /+\mathrm{Cd}$ plants were much less than those in $-\mathrm{Fe} /+\mathrm{Cd}$ and $-\mathrm{Fe} /-\mathrm{Cd}$ ones. When compared with $-\mathrm{Fe} / \mathrm{Cd}$ and $-\mathrm{Fe} /-\mathrm{Cd}$ plants, a marked improvement of bacteriod development and cell division was observed and deformation of cell wall remarkably alleviated in the nodules of $(+\mathrm{Fe} / \mathrm{Cd})$ plants. Proteomic study revealed that 20 proteins were differentially expressed by $\mathrm{Fe} / \mathrm{Cd}$ combined treatment. Eleven proteins of interest were identified and classified as precursor for RNA metabolism, storage of seeds, hypothetical proteins, and unknown proteins. These results indicate that $\mathrm{Fe}$ plays a pivotal role in alleviating
\end{abstract}

S. Muneer · M. I. Qureshi

Proteomics and Bioinformatics Lab, Department of

Biotechnology, Jamia Millia Islamia, New Delhi 110025, India

S. Muneer $(\bowtie) \cdot$ T. H. Kim

Department of Animal Science, Institute of Agricultural Science and Technology, College of Agriculture \& Life Science,

Chonnam National University, P.O Box 205, Buk-Gwangju,

Gwangju 500-600, Korea

e-mail: sobiyakhan126@gmail.com
Cd-stress, as evidence by reduction in oxidative damage and protection of cell wall and bacteriods in nodules.

Keywords Cd-stress $\cdot \mathrm{Fe} \cdot$ Nodules $\cdot$ Oxidative stress · Proteomics · Ultra-structure · Vigna radiata

\section{Introduction}

Cadmium is non-essential element that negatively affects plant growth and development of plant including root nodules. It is recognized as a significant major pollutant due to its considerable solubility and high toxicity (Pinto et al. 2004). Soil solutions contain Cd concentration ranging from 0.04 to $1 \mathrm{mM}$. Among several mechanisms of inducing toxicity, $\mathrm{Cd}$ can also alter the uptake of minerals by plants through its effect to reduce the availability of minerals from the soil, or through a reduction in the population of soil microbes (Maroco et al. 2002). Cd is well known to induce oxidative stress in plants including legume (Balestrasse et al. 2004). Cadmium can exert toxic effects through its high affinity for sulfuhydral groups in proteins and other biological molecules (Sanita di Toppi and Gabbrielli 1999; Fagioni et al. 2009) and may inhibit metabolic reactions in cell organelles of root-nodules. $\mathrm{Cd}$ stress often provokes the generation of reactive oxygen species (ROS) (Qadir et al. 2004). Although some of ROS may function as important signaling molecules that alter gene expression and modulate the activity of specific defense proteins, most ROS can be extremely harmful to organism because ROS can oxidize proteins, pigments, lipids, and nucleic acids which ultimately lead to alteration of cell structure and mutagenesis (Halliwell and Gutteridge 1999). Moreover, Cd-induced oxidative damage is often severe in Fe-defiency because Fe-deficiency provokes a 
large stimulation of $\mathrm{Cd}$ influx in plants (Qureshi et al. 2010) and vice versa affects them at different levels.

$\mathrm{Fe}$ is known to be essential for many physiological and biochemical processes including photosynthesis, respiration, DNA synthesis and $\mathrm{N}_{2}$-fixation. The legume-rhizobia symbiosis is particularly sensitive to Fe-deficiency (Tang et al. 1991). Fe-deficiency limits root nodule bacterial survival and multiplication, as well as host plant growth (O' Hara et al. 1998) because Fe involves in the development of nodules and their function (Ragland and Theil 1993; Krouma et al. 2006). In particular, Fe is required for some key proteins engaged in $\mathrm{N}_{2}$-fixation (nitrogenase, leghemoglobin) and in nitrogen assimilation (glutamate reductase, nitrate reductase) (Vanoni and Curti 2005; Clement et al. 2005). It has been reported that leghemoglobin and ferritin, important lipochito oligosaccharide hemoproteins, which involve in $\mathrm{N}_{2}$-fixation in root nodules of soybean was also affected by Cd stress (Balestrasse et al. 2004).

In recent, Qureshi et al. (2010) reported that Cd proved to be very deleterious to multiprotein complex, except for the PSII sub-complex, the light harvesting II monomer and free proteins under Fe deficiency, and that Fe proved very protective in retaining almost all the complexes. Some histological evidences in root nodules have shown that there is reduction in bacteriods, symbiosomes and reduced number of cell divisions (Balestrasse et al. 2004). Therefore, it may be hypothesized that $\mathrm{Fe}$ has a importance for the tolerance against Cd-induced stress especially in leguminous plants such as Vigna radiata (green gram) which ranks high among the pulse crops of India. Although the toxic effects of $\mathrm{Cd}$ and interaction between $\mathrm{Cd}$ and $\mathrm{Fe}$ have been widely documented in photosynthetic tissues (Sárvári et al. 1999; Sanita di Toppi and Gabbrielli 1999; Siedlecka and Krupa 1999; Qureshi et al. 2010; Muneer et al. 2011), relatively less in roots (Roth et al. 2006; Alvarez et al. 2009) but no related informations are in $\mathrm{N}_{2}$-fixing tissues in our knowledge.

In this study, we hypothesized that Fe modulates the $\mathrm{Cd}$ induced oxidative damage together with ultrastructure and proteome changes in nodules of Vigna radiata. To test this hypothesis, the responses of $\mathrm{Fe} / \mathrm{Cd}$ content in experimental soils, growth parameters, biochemical compounds, antioxidative activity, ultrastructure in root nodules were compared under Fe-sufficient and Fe-deficient conditions. Proteome changes in response to $\mathrm{Cd} / \mathrm{Fe}$ interaction were also analyzed.

\section{Materials and methods}

Plant material and $\mathrm{Fe} / \mathrm{Cd}$ treatment

Seeds of Vigna radiata L. var. Pusa vishal were obtained from IARI (Indian Agricultural Research Institute, Pusa, New Delhi, India. Surface sterilized seeds were sown in a plastic pot containing $4 \mathrm{~kg}$ of experimental soils: (1). irondeficient soil collected from the Agricultural Soil Science Unit, IARI (Indian Agricultural Research Institute) and (2) normal loamy soil. The seedlings were grown in a phytotron with day/night mean temperature of $25 / 22{ }^{\circ} \mathrm{C}$ under light intensity of $300 \mathrm{~m} \mathrm{~m}^{-2} \mathrm{~s}^{-1}$ with $14 \mathrm{~h}$ of photoperiod. Thirty days old plants grown on the Fe-sufficient as well

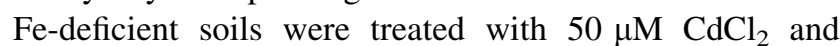
divided into four experimental treatments as (I) $+\mathrm{Fe} /-\mathrm{Cd}$ (control) (II) $+\mathrm{Fe} /+\mathrm{Cd}$ (III) $-\mathrm{Fe} /+\mathrm{Cd}$ (IV) $-\mathrm{Fe} /-\mathrm{Cd}$. Sampling was performed at 24 and $72 \mathrm{~h}$ after $\mathrm{Cd}$-exposure.

Estimation of iron content and $\mathrm{Cd}$ in experimental soils

Experimental soils $(500 \mathrm{mg}$ ) from all four treatments was digested in acid mixture $\left(\mathrm{HNO}_{3} / \mathrm{HCl}, 2 / 1\right.$, v/v), filtered (Whatman no. 42), and then diluted to appropriate volume. The Fe/Cd contents in the solution were estimated in ppm using a flame atomic absorption spectrometer (Video11; Thermo Jarrell Ash Corporation, Franklin, MA, USA).

Growth and physiological parameters

Plants were uprooted carefully by moving a spatula along with pot wall and roots were washed by dipping in a tube containing distilled water followed by blot-drying with very soft lint-free paper. Each plant was separated into root and nodules with the help of sharp scalpel and forceps in moist paper sheets, and then weighed for nodule and root biomasses.

Chlorophyll content was estimated by the method of (Hiscox and Israclstam 1979). Fresh leaves were collected in glass vials to which $10 \mathrm{ml}$ DMSO were added and were kept in an oven at $65{ }^{\circ} \mathrm{C}$ for complete leeching of pigments $1 \mathrm{~h}$. Optical density was recorded at 480, 645, 520 and $663 \mathrm{~nm}$. The chlorophyll concentrations in $\mathrm{mg}$ fresh samples were calculated using formulae given by Aronon and Israelstam (1979).

The lipid peroxidation level was determined by measuring the concentration of malondialdehyde (Heath and Packer 1968). One gram of fresh tissue was ground in $0.1 \%$ trichloroacetic acid (TCA) and centrifuged at $10,000 \mathrm{~g}$ for $5 \mathrm{~min}$. The mixture containing $1 \mathrm{ml}$ of supernatant with $0.5 \%$ thiobarbituric acid (TBA) was heated at $99{ }^{\circ} \mathrm{C}$ for $30 \mathrm{~min}$, cooled and centrifuged at $5,000 \mathrm{rpm}$ for $5 \mathrm{~min}$. The absorbance of the supernatant was read at $532 \mathrm{~nm}$ and corrected for unspecific turbidity after subtraction from the value obtained at $600 \mathrm{~nm}$.

Biochemical analysis

Ascorbate was determined by the method of Law et al. (1983). Five hundred milligram of grounded tissues was 
homogenized in phosphate buffer ( $\mathrm{pH}$ 7.4), centrifuged at $10,000 \mathrm{~g}$. Resulting supernatant was added with bipyridyl and $\mathrm{FeCl}_{3}$. The absorbance at $525 \mathrm{~nm}$ was measured.

Glutathione was estimated by the method of Anderson (1985). Five hundred milligram of fresh tissues was homogenized in $5 \%$ sulphosalicylic acid and centrifuged at $10,000 \mathrm{~g}$. Glutathione was estimated by adding dithionitrobenzoic acid (DTNB). The reaction was started by adding glutathione reductase for $30 \mathrm{~min}$ at $25^{\circ} \mathrm{C}$. The absorbance at $412 \mathrm{~nm}$ was immediately read.

Leghemoglobin was estimated using a flurometric method as described by (La Rue and Child 1979). Three hundred milligram of fresh nodules was homogenized in extraction buffer containing $0.02 \%(\mathrm{w} / \mathrm{v})$ potassium $(\mathrm{K})$, ferricyanide and $0.1 \%$ sodium bicarbonate. Homogenate was centrifuged at $10,000 \mathrm{~g}$ for $10 \mathrm{~min}$. Leghemoglobin in the red supernatant (nodule cytosol) obtained after centrifugation was quantified by using bovine hemoglobin as a standard.

For measurement of ferritin concentration, $300 \mathrm{mg}$ of fresh nodule was homogenized in cold $10 \mathrm{mM} \mathrm{KCl}$ HEPES ( $\mathrm{pH}$ 7.9) solution containing $10 \mathrm{mM} \mathrm{KCl}$ and $0.5 \mathrm{mM}$ dithiothriotol. Homogenates were centrifuged at $15,000 \mathrm{~g}$ for $5 \mathrm{~min}$. and Ferritin was estimated on Gel pro software by using standard horse ferritin and goat anti horse ferritin as primary and secondary antibody (Roskams and Connors 1994).

\section{Enzyme assays}

Ascorbate peroxidise (APX) activity was estimated by measuring the decrease in absorbance at $290 \mathrm{~nm}$ (extinction coefficient of absorbance $2.8 \mathrm{mM}^{-1} \mathrm{~cm}^{-1}$ for ascorbate) according to Nakano et al. (2006). One hundred milligram of fresh tissue were extracted in $100 \mathrm{mM}$ K-phosphate ( $\mathrm{pH} 7.0$ ), and then centrifuged at 15,000 $\mathrm{g}$ for 10 min. One unit of enzyme was expressed as the amount necessary to decompose $1 \mu$ mole of ascorbate per min.

Superoxide dismutase (SOD) activity was determined by the method of Dhindsa et al. (1981) with minor modifications. Fresh tissues $(200 \mathrm{mg})$ were extracted in phosphate buffer $(\mathrm{pH} 7.3)$ and centrifuged at $15,000 \mathrm{~g}$. SOD activity in the supernatant was assayed by its ability to inhibit photochemical reduction of nitroblue tetrazolium (NBT) by reading the absorbance at $560 \mathrm{~nm}$. One unit of enzyme activity was defined as the amount of enzyme required to inhibit $50 \%$ of the NBT photo reduction in comparison with tubes lacking the plant extract.

Catalase (CAT) activity was determined by the method of (Aebi 1984). About $500 \mathrm{mg}$ of grounded tissues were extracted in phosphate buffer $(\mathrm{pH} 7.3)$, centrifuged at $15,000 \mathrm{~g}$ for $20 \mathrm{~min}$. The decrease in absorbance at $240 \mathrm{~nm}$ was recorded as a result of $\mathrm{H}_{2} \mathrm{O}_{2}$ degradation (extinction coefficient of $36 \mathrm{mM}^{-1} \mathrm{~cm}^{-1}$ ). One unit of enzyme determines the amount necessary to decompose $1 \mu \mathrm{m}$ of $\mathrm{H}_{2} \mathrm{O}_{2}$ per min.

Glutathione reductase (GR) activity was determined by the method of Rao (1992). About $500 \mathrm{mg}$ of fresh tissues were extracted in phosphate buffer $(\mathrm{pH} 7.0)$, centrifuged at $15,000 \mathrm{~g}$ for $10 \mathrm{~min}$. The supernatant was immediately assayed for GR activity through glutathione-dependent oxidation of NADPH at $340 \mathrm{~nm}$. One unit of enzyme determines its amount necessary to decompose $1 \mu$ mole of NADPH per min.

\section{Electron microscopy}

Harvested mature nodules at $72 \mathrm{~h}$ of Cd-exposure were was cut into app. $1 \mathrm{~mm}$ pieces with a sharp blade and stored in fixing solution containing $1 \%$ formaldehyde, $2.5 \%$ glutaryldehyde and $2 \%$ paraformaldehyde overnight at $4{ }^{\circ} \mathrm{C}$. Nodule samples were washed with $100 \mathrm{mM}$ phosphate buffer ( $\mathrm{pH} 7.4$ ), placed in osmium tetraoxide for $2 \mathrm{~h}$ at $4{ }^{\circ} \mathrm{C}$, After washing again with phosphate buffer, dehydration with acetone 30-90\% was followed. Finally samples were dehydrated in dry acetone (saturated with copper sulphate) for $1 \mathrm{~h}$ at $4{ }^{\circ} \mathrm{C}$. Samples were cleaned with toluene, twice for $1 \mathrm{~h}$ each and placed in resin and toluene $(1: 3, \mathrm{w} / \mathrm{v})$ overnight in vacuum followed by impregnation again in resin and toluene (2:2 and 3:1) overnight in vacuum before being finally impregnated in pure resin for $6 \mathrm{~h}$ at room temperature. Samples were embedded with resin in flat molds. Thin sections of the size of $1-2 \mu \mathrm{m}$ were cut and stained in with methylene blue for 20-40 s. Grids were made of the size of 60-90 $\mathrm{nm}$ and stained with heavy metal solution (uranyle acetate and lead citrate). The stained sections were placed on a transmission electron microscope (Model CMIO, TEM, Phillips). Interior regions with comparable structures were surfed and the pictures were digitized.

Proteomic analysis

Mature nodules harvested at $72 \mathrm{~h}$ of $\mathrm{Cd}$-exposure were grounded in liquid nitrogen to a fine powder extracted for protein with $40 \mathrm{mM}$ Tris- $\mathrm{HCl}$ extraction ( $\mathrm{pH}$ 7.5) according to Molloy et al. (1998). Homogenate was centrifuged at 20,000 rpm for $60 \mathrm{~min}$ at $4{ }^{\circ} \mathrm{C}$. Resulting supernatant was incubated over night with chilled $12 \%$ TCA-acetone, centrifuged at $15,000 \mathrm{rpm}$ for $15 \mathrm{~min}$. Resulting pellet was washed with chilled acetone containing $0.07 \% \beta$-mercaptoethanol and $2 \mathrm{mM}$ EDTA, and then centrifuged at $20,000 \mathrm{~g}$ for $15 \mathrm{~min}$. Pure white pellet recovered was vacuum dried and solubilized in solubilization cocktail containing $9 \mathrm{M}$ urea, $2 \mathrm{M}$ thiourea, $2 \%$ Triton X 100, $4 \%$ CHAPS, $0.2 \%$ ampholine and $50 \mathrm{mM}$ DTT at room temperature for $60 \mathrm{~min}$. Protein concentration was determined by standard Bradford assay using 
bovine serum albumin as standard (Bio-Rad, Hercules, CA, USA). Immobilized $\mathrm{pH}$ gradient (IPG) strips (ReadyStrip $^{\text {TM }}$, Bio-Rad, USA) of $11 \mathrm{~cm}$, non-linear with $\mathrm{pH}$ 3-10 were passively rehydrated overnight with $150 \mu \mathrm{g}$ of protein sample. Isoelectric focusing (IEF) of proteins was performed using the following programme: 50 volts for $60 \mathrm{~min}, 150$ volts for $30 \mathrm{~min}, 300$ volts for $30 \mathrm{~min}, 500$ volts for $120 \mathrm{~min}, 3,000$ volts until a total of 72,000 volthours had been achieved. After IEF, strips were equilibrated in buffer containing $7 \mathrm{M}$ urea, $2 \%$ SDS, $375 \mathrm{mM}$ Tris (pH 8.8), and $20 \%$ glycerol plus either $130 \mathrm{mM}$ DTT for reduction or $135 \mathrm{mM}$ IAA for alkylation. Equilibrated IPG strips were loaded onto a $12 \%$ acrylamide gel, and electrophoresed by applying a voltage of 100 volts at $10^{\circ} \mathrm{C}$. Gels were stained with Coomassie Brilliant Blue R-250 and images were acquired on a gel documentation system (Bio-Rad, USA) at $300 \mathrm{dpi}$ and saved as a gray scale. Experimental molecular weight and $\mathrm{p} I$ values were calculated from digitized images using molecular weight marker proteins and the predicted non-linear $\mathrm{pH}$ gradient provided by Bio-Rad USA. Protein spots were detected and numbered with PD Quest image analysis software (Bio-Rad, USA). The protein expression patterns were determined as up-regulated, down-regulated and unchanged compared to control. Three independent experimental replicates were used for proteomic analysis. The differentially expressed proteins were spot picked, digested with trypsin and identified by LC/MSMS.

\section{Stastical analysis}

SAS 9.0 software (SAS Institute Inc, 2002) was used for statistical analysis. The experiment was done as randomized block design. The mean and standard deviation was done for bar diagrams with percent variation. Analysis of variance (ANOVA) was done with all the data to confirm the variability of the data and validity of results.

\section{Results}

Fe and Cd content

The content of $\mathrm{Fe}$ in all four treated soils were estimated and it was observed that $\mathrm{Fe}$ content in $-\mathrm{Fe} /-\mathrm{Cd}$ was decreased compared to control and was more severely decreased in $-\mathrm{Fe} /+\mathrm{Cd}$ plants (Fig. 1a) whereas in $+\mathrm{Fe} /$ $+\mathrm{Cd}$ plants the content of $\mathrm{Fe}$ was increased.

The $\mathrm{Cd}$ content increased in $+\mathrm{Fe} /+\mathrm{Cd}$ compared to control which was more severely increased in $-\mathrm{Fe} /+\mathrm{Cd}$ plants however, in $-\mathrm{Fe} /-\mathrm{Cd}$ and in control plants the content of $\mathrm{Cd}$ was found in trace amounts (Fig. 1b).
Plant growth parameters, chlorophyll and protein

Cd-exposure significantly decreased shoot and root length compared to those of non -Cd-exposed control $(+\mathrm{Fe} /-\mathrm{Cd})$ plants. These decreases were more severe in $\mathrm{Fe}$-deficient $(-\mathrm{Fe} /+\mathrm{Cd})$ compared to those in $\mathrm{Fe}$-sufficient soils $(+\mathrm{Fe} /+\mathrm{Cd})$ and $-\mathrm{Fe} /-\mathrm{Cd}$ (act as additional control) (Table 1). A significant decline in total chlorophyll content was apparent only in $-\mathrm{Fe} / \mathrm{Cd}$ plants. A drastic decrease of about 79 and $81.5 \%$ was observed in protein content in $-\mathrm{Fe} /+\mathrm{Cd}$ (Fig. 2a), whereas the decreases was much less in $+\mathrm{Fe} /+\mathrm{Cd}$ plants.

Nodule development and concentration of leghemoglobin and ferritin in nodules

Nodule number significantly decreased only in $-\mathrm{Fe} /+\mathrm{Cd}$ plants as compared to control (Table 1). Cd-exposure significantly decreased nodule biomass, leghemoglobin and ferritin concentration compared to control and the reduction was more in $-\mathrm{Fe} /+\mathrm{Cd}$ plants and less in $-\mathrm{Fe} /-\mathrm{Cd}$ plants. In $-\mathrm{Fe} /+\mathrm{Cd}$ plants nodule biomass was reduced by 70 and $80 \%$, respectively, after 24 and $72 \mathrm{~h}$ of sampling whereas in $+\mathrm{Fe} /+\mathrm{Cd}$ plants only 40 and $50 \%$ were reduced (Table 1 ).
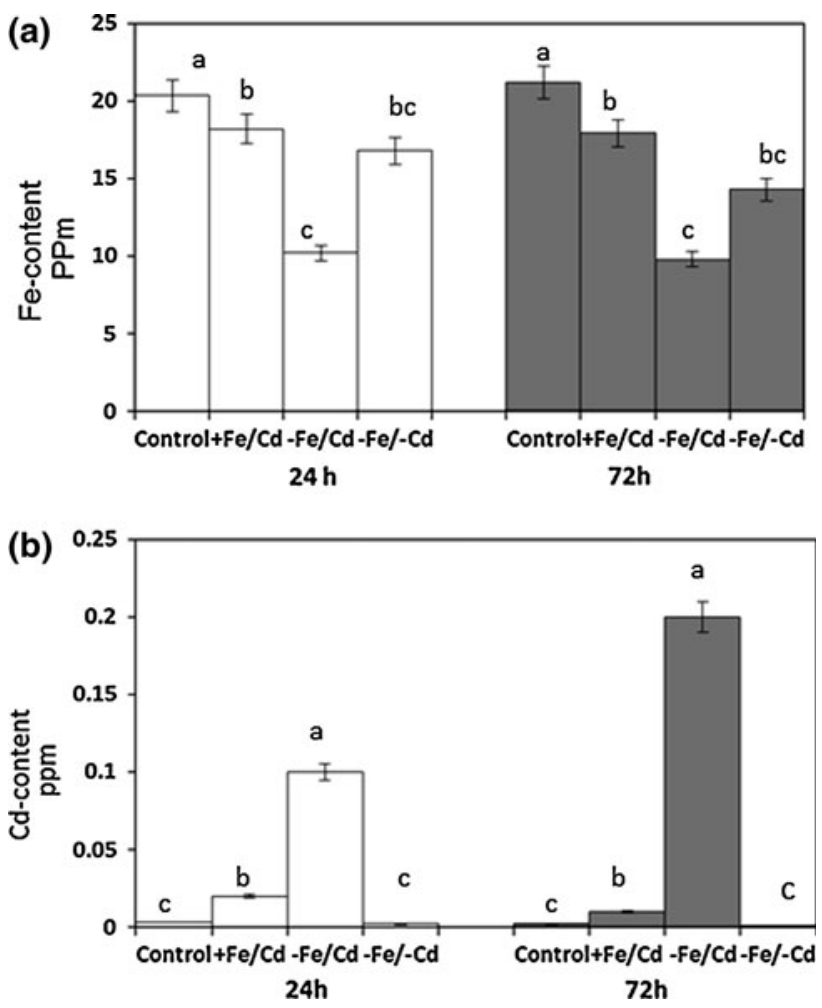

Fig. 1 a $\mathrm{Fe}$ and $\mathbf{b} \mathrm{Cd}$ content in experimental soils of non $-\mathrm{Cd}$-exposed (control) or Cd-exposed under Fe-sufficient $(+\mathrm{Fe} / \mathrm{Cd})$ and $\mathrm{Fe}$-deficient $(-\mathrm{Fe} / \mathrm{Cd})$ with additional control $(-\mathrm{Fe} /-\mathrm{Cd})$ after 24 and $72 \mathrm{~h}$ of Cd-exposure. Vertical bars indicate mean \pm SE for $\mathrm{n}=4$ 
Table 1 Changes in shoot, root length of host plant, chlorophyll, nodule number and biomass under Fe-deficiency and Cd-stress conditions for 24 and $72 \mathrm{~h}$ after treatment

\begin{tabular}{|c|c|c|c|c|c|}
\hline \multirow[t]{2}{*}{ Hours after treatment } & \multicolumn{5}{|l|}{ Parameters } \\
\hline & $\begin{array}{l}\text { Shoot length } \\
(\mathrm{cm})\end{array}$ & Root length (cm) & $\begin{array}{l}\text { Chlorophyll } \\
\left(\mathrm{mg} \mathrm{g}^{-1} \mathrm{FW}\right)\end{array}$ & $\begin{array}{l}\text { Nodule number } \\
\left(\text { ng plant }^{-1}\right)\end{array}$ & $\begin{array}{l}\text { Nodule biomass/ } \\
\text { treatment (ng plant }{ }^{-1} \text { ) }\end{array}$ \\
\hline \multicolumn{6}{|l|}{$24 \mathrm{~h}$ after treatment } \\
\hline Control & $5.6 \pm 0.15^{\mathrm{a}}$ & $48.2 \pm 0.81^{\mathrm{a}}$ & $0.17 \pm 0.123^{\mathrm{a}}$ & $1.05 \pm 1.01^{\mathrm{a}}$ & $1.4 \pm 0.99^{\mathrm{a}}$ \\
\hline$+\mathrm{Fe} / \mathrm{Cd}$ & $3.4 \pm 0.14^{\mathrm{b}}$ & $39.1 \pm 0.24^{\mathrm{b}}$ & $0.16 \pm 0.11^{\mathrm{a}}$ & $0.50 \pm 0.38^{\mathrm{b}}$ & $0.4 \pm 0.28^{\mathrm{b}}$ \\
\hline$-\mathrm{Fe} / \mathrm{Cd}$ & $2.5 \pm 0.05^{\mathrm{c}}$ & $10.7 \pm 0.11^{\mathrm{c}}$ & $0.04 \pm 0.02^{\mathrm{b}}$ & $0.26 \pm 0.18^{\mathrm{c}}$ & $0.1 \pm 0.07^{\mathrm{b}}$ \\
\hline$-\mathrm{Fe} /-\mathrm{Cd}$ & $3.1 \pm 0.01^{\mathrm{bc}}$ & $29.7 \pm 0.21^{\mathrm{bc}}$ & $0.15 \pm 0.11^{\mathrm{bc}}$ & $0.45 \pm 0.21^{\mathrm{bc}}$ & $0.2 \pm 0.01^{\mathrm{bc}}$ \\
\hline \multicolumn{6}{|l|}{$72 \mathrm{~h}$ after treatment } \\
\hline Control & $5.7 \pm 0.08^{\mathrm{a}}$ & $50.8 \pm 0.05^{\mathrm{a}}$ & $0.17 \pm 0.125^{\mathrm{a}}$ & $1.43 \pm 1.01^{\mathrm{a}}$ & $1.4 \pm 0.99^{\mathrm{a}}$ \\
\hline$+\mathrm{Fe} / \mathrm{Cd}$ & $3.4 \pm 0.11^{\mathrm{b}}$ & $9.70 \pm 0.05^{\mathrm{b}}$ & $0.16 \pm 0.11^{\mathrm{a}}$ & $0.43 \pm 0.38^{\mathrm{b}}$ & $0.2 \pm 0.14^{\mathrm{b}}$ \\
\hline$-\mathrm{Fe} / \mathrm{Cd}$ & $1.8 \pm 0.05^{\mathrm{c}}$ & $2.60 \pm 0.08^{\mathrm{c}}$ & $0.03 \pm 0.02^{\mathrm{b}}$ & $0.16 \pm 0.18^{\mathrm{c}}$ & $0.1 \pm 0.07^{\mathrm{b}}$ \\
\hline$-\mathrm{Fe} /-\mathrm{Cd}$ & $2.5 \pm 0.01^{\mathrm{bc}}$ & $8.7 \pm 0.04^{\mathrm{bc}}$ & $0.15 \pm 0.11^{\mathrm{bc}}$ & $0.39 \pm 0.21^{\mathrm{bc}}$ & $0.3 \pm 0.11^{\mathrm{bc}}$ \\
\hline
\end{tabular}

The values given are mean $\pm \mathrm{SE}(\mathrm{n}=5)$ significantly different at $P<0.05$ as determined by Tukey's studentized range test (HSD)

Means with the same letter $(\mathrm{a}, \mathrm{b}$, and $\mathrm{c}$ ) are not significantly different, where as, means with different letter $(\mathrm{a}, \mathrm{b}$, and c) are significantly different

Leghemoglobin concentration at $72 \mathrm{~h}$ of $\mathrm{Cd}$-exposure was reduced by $19.4 \%$ in $+\mathrm{Fe} /+\mathrm{Cd}$, while up to $63.4 \%$ in $-\mathrm{Fe} /$ $+\mathrm{Cd}$ plants compared control however, less decreased in $-\mathrm{Fe} /-\mathrm{Cd}$ plants compared to that of control (Fig. 2b). Cd-exposure remarkably decreased ferritin concentration by 81.6 and $92.2 \%$ at 24 and $72 \mathrm{~h}$ in $-\mathrm{Fe} /+\mathrm{Cd}$ plants, while decreased by only by 11.9 and $33.3 \%$ in $+\mathrm{Fe} /+\mathrm{Cd}$ plants whereas, less affect was observed in $-\mathrm{Fe} /-\mathrm{Cd}$ as compared to those of control (Fig. 2c).

Lipid peroxidation, ascorbate and glutathione

Lipid peroxidation was significantly increased by $\mathrm{Cd}$ exposure under Fe-deficient condition $(-\mathrm{Fe} /+\mathrm{Cd})$, but no significant change occurred under Fe-sufficient $(+\mathrm{Fe} /+\mathrm{Cd})$ compared to control (Fig. 3a) however, in $-\mathrm{Fe} /-\mathrm{Cd}$ plants lipid peroxidation was less affected compared to $-\mathrm{Fe} /+\mathrm{Cd}$ plants when compared to that of control. Total glutathione concentration were reduced by 28.5 and $22.3 \%$ at 24 and $72 \mathrm{~h}$ after $\mathrm{Cd}$-exposure in $-\mathrm{Fe} /+\mathrm{Cd}$, whereas they increased by 86 and $49.6 \%$ in $+\mathrm{Fe} / \mathrm{Cd}$ plants compared to controls and was less affected in $-\mathrm{Fe} /-\mathrm{Cd}$ plants (Fig. 3b). Similarly, total ascorbate concentration were reduced by 18.8 and $46.5 \%$ at 24 and $72 \mathrm{~h}$ after Cd-exposure in $-\mathrm{Fe} /$ $+\mathrm{Cd}$ and least decreased in $-\mathrm{Fe} /-\mathrm{Cd}$ plants (Fig. 3c), whereas they increased by 9.4 and $34.1 \%$ in $+\mathrm{Fe} /+\mathrm{Cd}$ plants compared to controls.

Antioxidant enzymes activity

The response of all antioxidative enzymes examined in this study was in exquisite contrast between Fe-sufficient and Fe-deficient condition. Cd-exposure increased APX, SOD,
CAT and GR activity under Fe-sufficient (Fig. 4a, b, c, d), while inversely decreased under Fe-deficient condition at alltime courses of measurement when compared with control and in $-\mathrm{Fe} /-\mathrm{Cd}$ plants the antioxidant enzymes were less decreased compared to control. At $72 \mathrm{~h}$ of Cd-exposure, APX, SOD, CAT and GT activity was increased by 10.0 , 26.3, 30.2 and $22.7 \%$ respectively under Fe-sufficient soil compared to those of control, but decreased by 64.1, 35.4, 29.8 and $64.3 \%$ respectively under Fe-deficient soil.

Ultrastructure of nodules

Electron micrograph revealed that $\mathrm{Cd} / \mathrm{Fe}$ individual and/or combined impact closely associated with the histological changes of nodules (Fig. 5). In control plants, the bacteriods were well developed and distributed evenly in cytoplasm (Fig. 5a) and cell wall was keeping normal shape in a general form (Fig. 5e). Cd-exposure $(+\mathrm{Fe} /+\mathrm{Cd})$ resulted in the reduction of cell division and dislocation of bacteriods in cytoplasm (Fig. 5b) and provoked also deformation of cell wall (Fig. 5f) in the nodules. In the plants under Fe-deficient condition $(-\mathrm{Fe} /+\mathrm{Cd})$, number of bacteriods largely decreased and cell division was strictly restricted (Fig. 5c), together with a distorted and ruptured shape of cell wall (Fig. 5g). When compared with $-\mathrm{Fe} /+\mathrm{Cd}$ plants, a marked increase in bacteriods and cell number was observed (Fig. 5c) and deformation of cell wall remarkably alleviated in the nodules fed with sufficient $\mathrm{Fe}(+\mathrm{Fe} /+\mathrm{Cd})$ even though distorted parts were still observed (Fig. 5f). In $-\mathrm{Fe} /-\mathrm{Cd}$ plants the bacteriods were reduced in number (Fig. 5d) and cell wall was also deformed at certain positions (Fig. 5h) because of absence of Fe when compared to control however, was least affected when compared to $-\mathrm{Fe} /+\mathrm{Cd}$ plants. These 

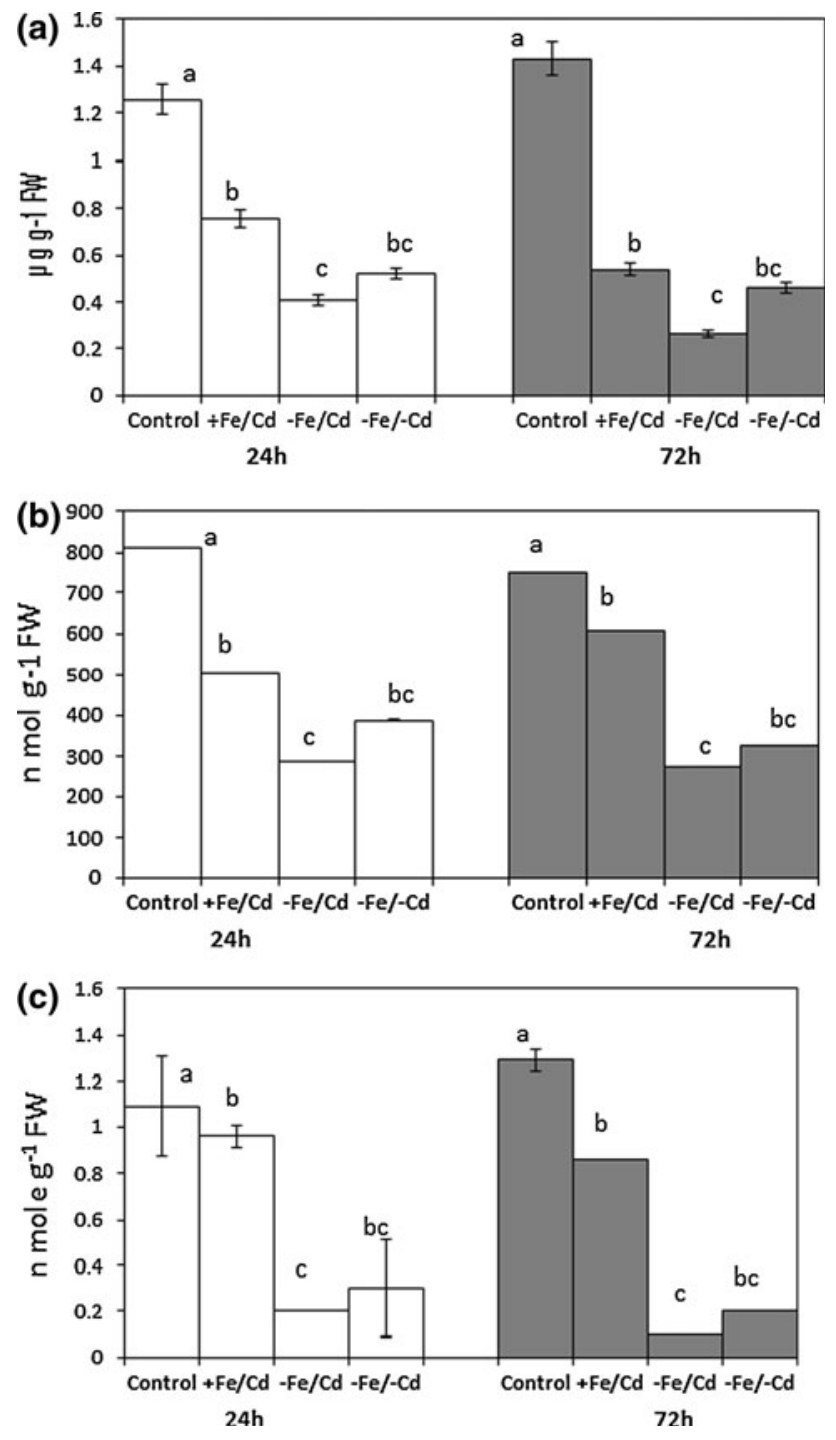

Fig. 2 Changes in protein content (a), leghemoglobin (b) and ferritin concentration (c) in root nodules of non -Cd-exposed (control) or $\mathrm{Cd}$-exposed under Fe-sufficient $(+\mathrm{Fe} / \mathrm{Cd})$ and $\mathrm{Fe}$-deficient $(-\mathrm{Fe} / \mathrm{Cd})$ with additional control $(-\mathrm{Fe} /-\mathrm{Cd})$ after 24 and $72 \mathrm{~h}$ of Cd-exposure. Vertical bars indicate mean $\pm \mathrm{SE}$ for $\mathrm{n}=4$

provided important clues of the potential role of Fe in mitigating the Cd-induced damage in nodule structure.

Proteomic analysis of root nodules

First dimensional electrophoresis were run on IPG strips to focus the proteins from root-nodules harvested after $72 \mathrm{~h}$ of Cd-exposure and the focused proteins were separated by the 2nd dimension SDS-PAGE. Figure 6 showed 2D gel profile of differentially expressed proteins in root-nodules obtained from different experimental (treatments) sets, viz. (I) control (II) $+\mathrm{Fe} / \mathrm{Cd}$ (III) $-\mathrm{Fe} / \mathrm{Cd}$ (IV) $-\mathrm{Fe} /-\mathrm{Cd}$. While comparing the $2 \mathrm{D}$ gels of root-nodules it was found protein profile was more affected under $-\mathrm{Fe} / \mathrm{Cd}$ stress compared to
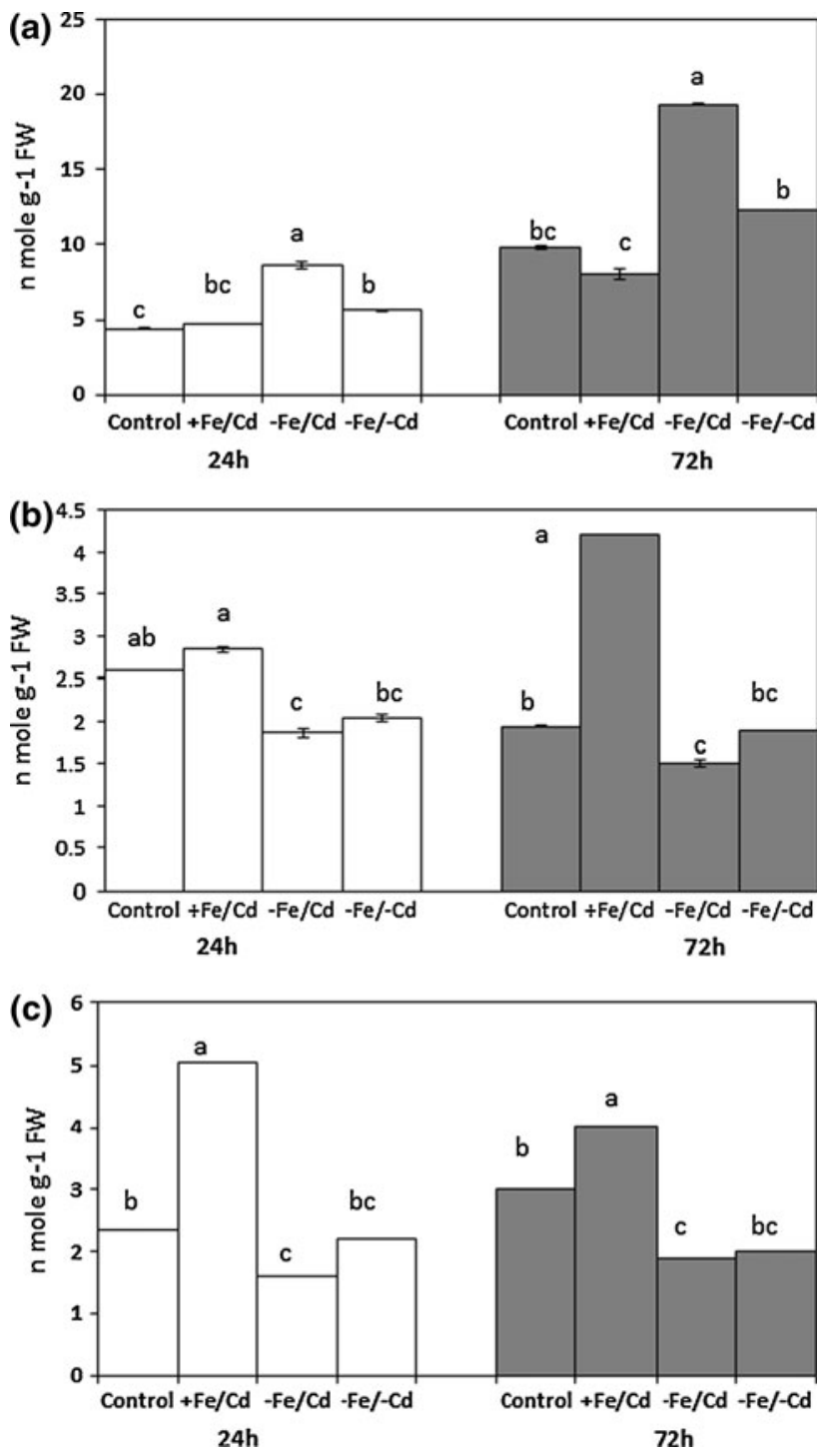

Fig. 3 Changes in lipid peroxidation (a), total glutathione (b) and total ascorbate (c) in root nodules of non $-\mathrm{Cd}$ exposed (control) or Cd-exposed under Fe-sufficient $(+\mathrm{Fe} / \mathrm{Cd})$ and $\mathrm{Fe}$-deficient $(-\mathrm{Fe} / \mathrm{Cd})$ with additional control $(-\mathrm{Fe} /-\mathrm{Cd})$ after 24 and $72 \mathrm{~h}$ of Cd-exposure. Vertical bars indicate mean \pm SE for $\mathrm{n}=4$

$+\mathrm{Fe} /+\mathrm{Cd}$. This implies that $\mathrm{Fe}$ seemed to greatly help plants in counteracting the negative effects of $\mathrm{Cd}$ treatment by retaining quantity of proteins and quality of root-nodules While comparing with $-\mathrm{Fe} /+\mathrm{Cd}$ plants the protein profile was well astonished in $-\mathrm{Fe} /-\mathrm{Cd}$ plants (Fig. 5d). Approximately 150 spots were detected on 2-D gels of nodule proteins among these spots, about 20 spots were found to be differentially expressed (Fig. 6). Furthermore, 11 protein spots out of 20 differentially proteins were positively identified by LC/MSMS as listed in Table 2 with information about matched peptides and ion score, nevertheless it was identified that differentially expressed proteins were predicted to be RNA rich binding and 

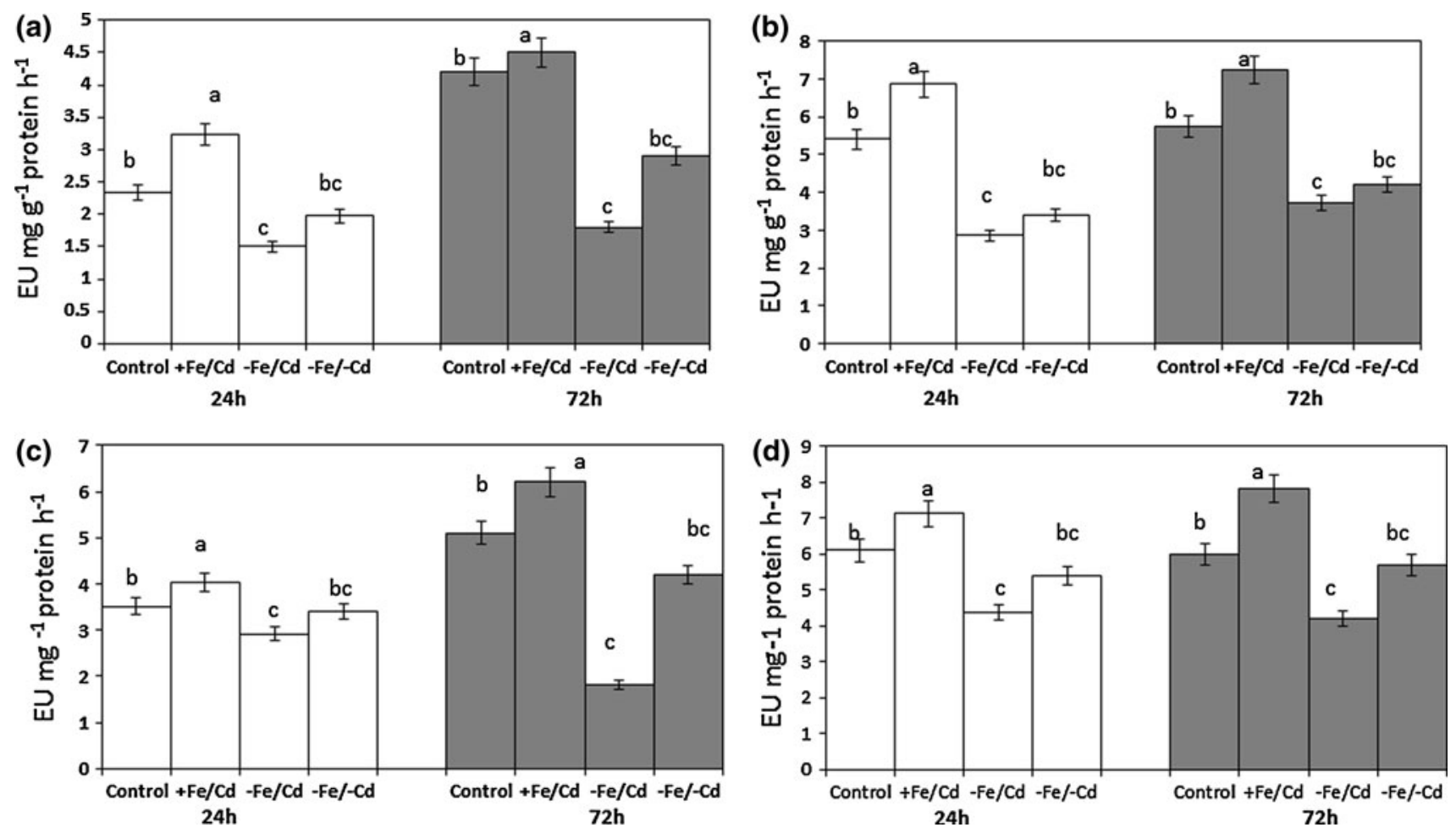

Fig. 4 Changes in antioxidant enzyme activities; ascorbate peroxidase (APX) (a), superoxide dismutase (SOD) (b), catalase (CAT) (c) and glutathione reductase (GR) in root nodules of non $-\mathrm{Cd}$ exposed (control) or $\mathrm{Cd}$-exposed under $\mathrm{Fe}$-sufficient $(+\mathrm{Fe} / \mathrm{Cd})$ and

Fe-deficient $(-\mathrm{Fe} / \mathrm{Cd})$ with additional control $(-\mathrm{Fe} /-\mathrm{Cd})$ after 24 and $72 \mathrm{~h}$ of Cd-exposure. Vertical bars indicate mean $\pm \mathrm{SE}$ for $\mathrm{n}=4$

hypothetical proteins. To further examine differentially expressed proteins due to combined effect of $\mathrm{Fe} / \mathrm{Cd}$, the identified proteins were divided into four functional categories using Map Man ontology classified by Beven et al. (1998) as shown in Fig. 7, including RNA metabolism, hypothetical proteins, secondary metabolism and proteins yet not assigned with function.

Correlation between $\mathrm{Fe} / \mathrm{Cd}$ and other parameters

Linear correlation among $\mathrm{Fe} / \mathrm{Cd}$ with related parameters was assessed. The measurements were normalized between the values measured in $\mathrm{Fe}$-deficient or $\mathrm{Fe}$-sufficient plants with exposure and non-exposure to $\mathrm{Cd}$. The Fe concentration was positively correlated to Soluble protein $\left(\mathrm{r}=0.81^{* * *}\right)$, total ascorbate $\left(\mathrm{r}=0.518^{* *}\right)$ and other related parameters. The correlation values are shown in Table 3. Similarly the correlation between Cd-concentration with other related parameters were also assessed shown in Table 3 .

\section{Discussion}

The present study indicated that $\mathrm{Cd}$ has a toxic effect on host plant growth and nodule development of Vigna

radiata. The concentration $\mathrm{Fe} / \mathrm{Cd}$ analyzed in experimental soils indicated that $\mathrm{Fe}$ has greater effect on alleviating $\mathrm{Cd}$ stress by indicating that $\mathrm{Fe}$ content highly decreased in $-\mathrm{Fe} /-\mathrm{Cd}$ plants while increased in $-\mathrm{Fe} /+\mathrm{Cd}$ plants (Fig. 1a) whereas $\mathrm{Cd}$ content was negligible in control plants which increased in $-\mathrm{Fe} /-\mathrm{Cd}$ plants however, decreased in $+\mathrm{Fe} /+\mathrm{Cd}$ plants (Fig. 1b). These results were consistent with previous results of barley roots under $\mathrm{S}$ and $\mathrm{Fe}$ deficiency in relation to Cd-exposure (Astolfi et al. 2012). Cd-exposure reduced significantly leaf, root length, chlorophyll content of host plant, also decreased the number and biomass of nodules (Table 1). The negative effects of Cd-exposure on these parameters appeared to be much less in the plants fed with sufficient $\mathrm{Fe}(+\mathrm{Fe} /+\mathrm{Cd})$ than in deficient $\mathrm{Fe}(-\mathrm{Fe} /+\mathrm{Cd})$ and non-exposed cadmium $(-\mathrm{Fe} / \mathrm{Cd})$. The toxic effects of $\mathrm{Cd}$ induced oxidative stress as evidenced by the increased lipid peroxidation level (Fig. 3a). Lipid peroxidation has been considered as one of serious phytotoxic consequences of reactive oxygen species (ROS) generation (Ali et al. 2005; Lee et al. 2009). In this study, Cd-exposure resulted in the reduction in total glutathione and ascorbate content under Fe-deficient condition (Fig. 3b, c) and the activity of antioxidative enzymes (APX, SOD, CAT, GR) (Fig. 4), whereas they were significantly increased under Fe-sufficient condition whereas, 
A
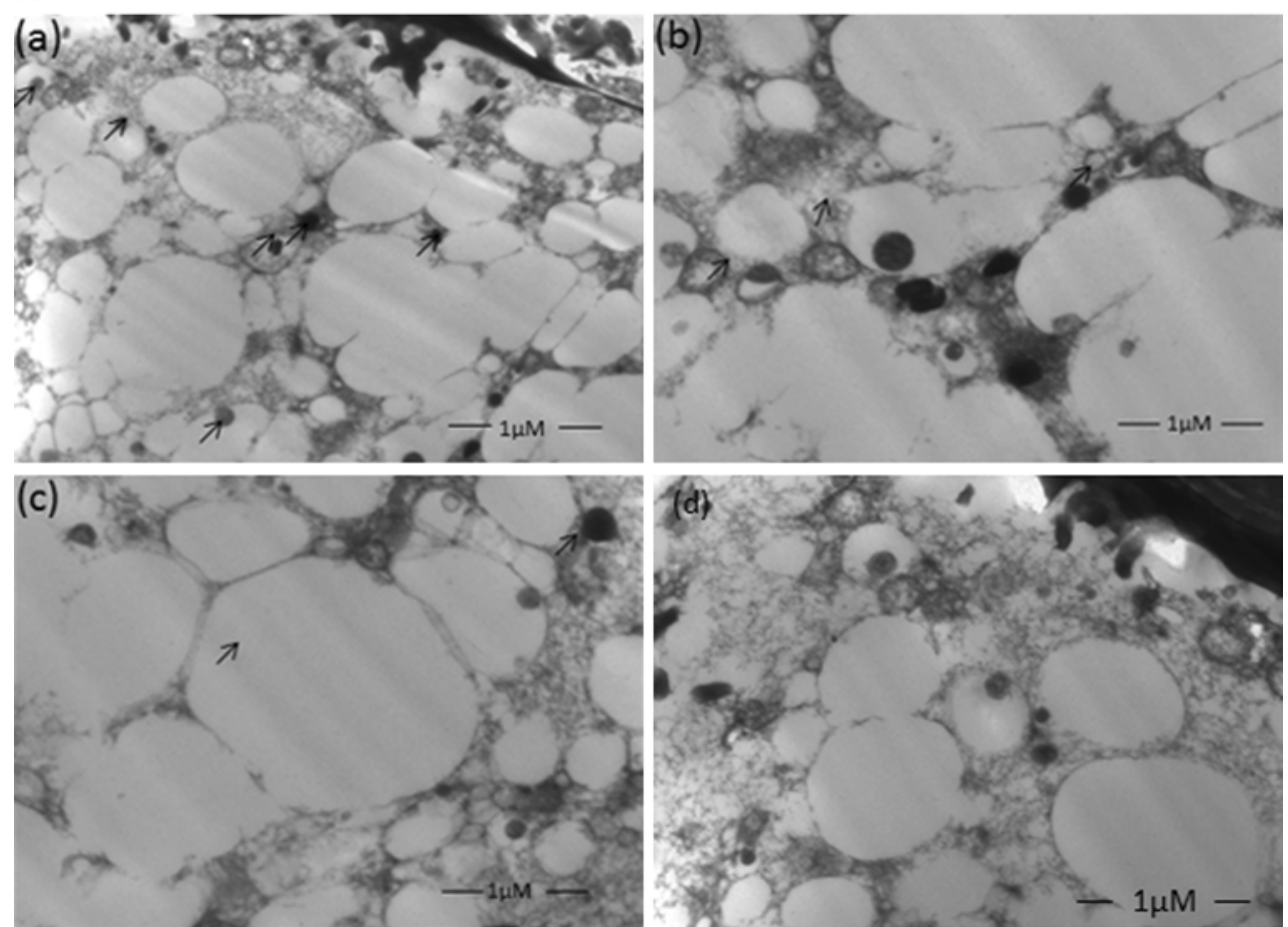

B
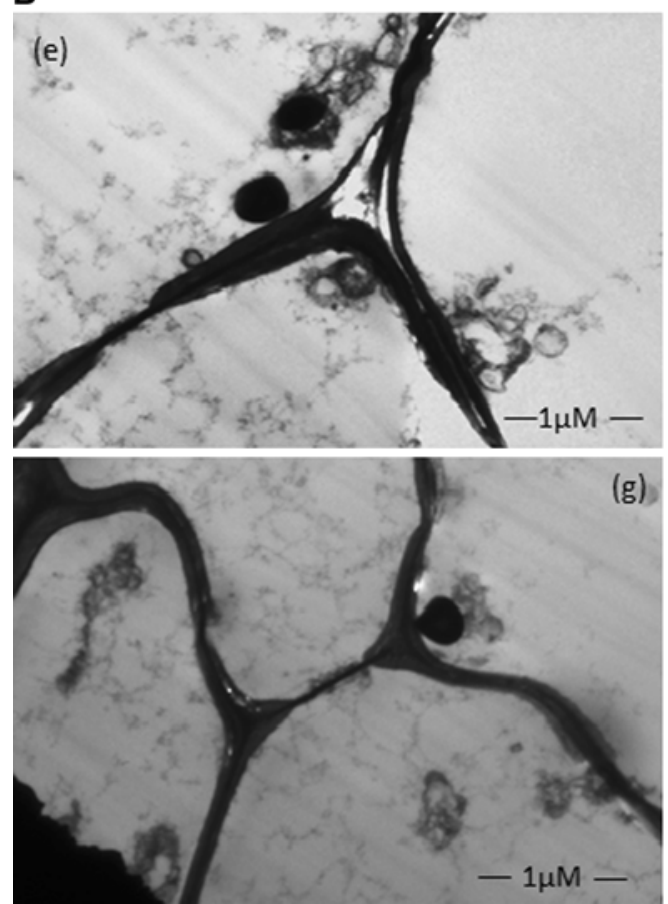

(g)
Fig. 5 a Figures show micrograph developed electron-Microscopy (TEM) technique of electron microscopy (EM). TEM of nodule obtained from control $(+\mathrm{Fe} / \mathrm{Cd})$ plants show normal growth with regular features of typical nodule $(a)$ such as normal cell growth with embedded bacteriods in cytoplasm. $b$ depicts $(-\mathrm{Fe} / \mathrm{Cd})$ absence of bacteriods, reduced cell divisions, $c$ depicts $(+\mathrm{Fe} / \mathrm{Cd})$ reduction in bacteriods, cell divisions eventually ceased up, $d$ depicts $(-\mathrm{Fe} /-\mathrm{Cd})$ reduction in bacteriods and act as an additional control. b Figures
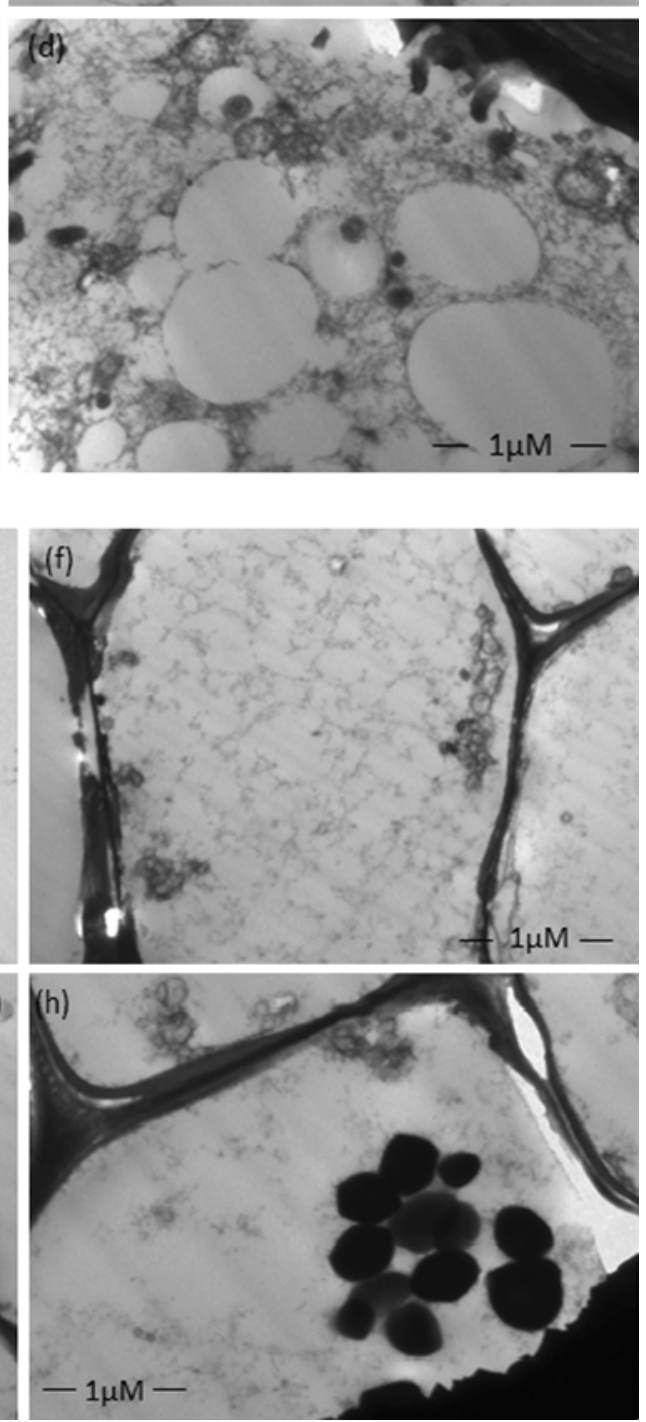

show micrograph developed electron-Microscopy (TEM) technique of electron microscopy (EM). TEM of nodule obtained from control $(+\mathrm{Fe} / \mathrm{Cd})$ plants show normal cell wall formation $(e, d) . f$ depicts $(-\mathrm{Fe} / \mathrm{Cd})$ Reduction in cell wall formation, $g$ depicts $(+\mathrm{Fe} / \mathrm{Cd})$ reduction in cell wall compared to control however, recovered by giving $\mathrm{Fe}, h$ depicts $(-\mathrm{Fe} /-\mathrm{Cd})$ as additional control and cell wall formation reduced 
Fig. 6 Differentially expressed proteins in root nodules $(\mathbf{a}=+\mathrm{Fe} /-\mathrm{Cd}, \mathbf{b}=-\mathrm{Fe} /+\mathrm{Cd}$, $\mathbf{c}=-\mathrm{Fe} / \mathrm{Cd}, \mathbf{d}=-\mathrm{Fe} /-\mathrm{Cd})$ of Vigna radiata in response to $\mathrm{Fe}$ deficiency and Cd stress. Protein samples $(150 \mu \mathrm{g})$ were separated on 2D gel (pI 3-10) and Coomassie stained. Data analysis was performed using PD quest software program. The relative $\mathrm{Mr}$ is indicated on left side in $\mathrm{kDa} .20$ differentially proteins were analyzed by LC/MSMS among which only 11 spots were identified

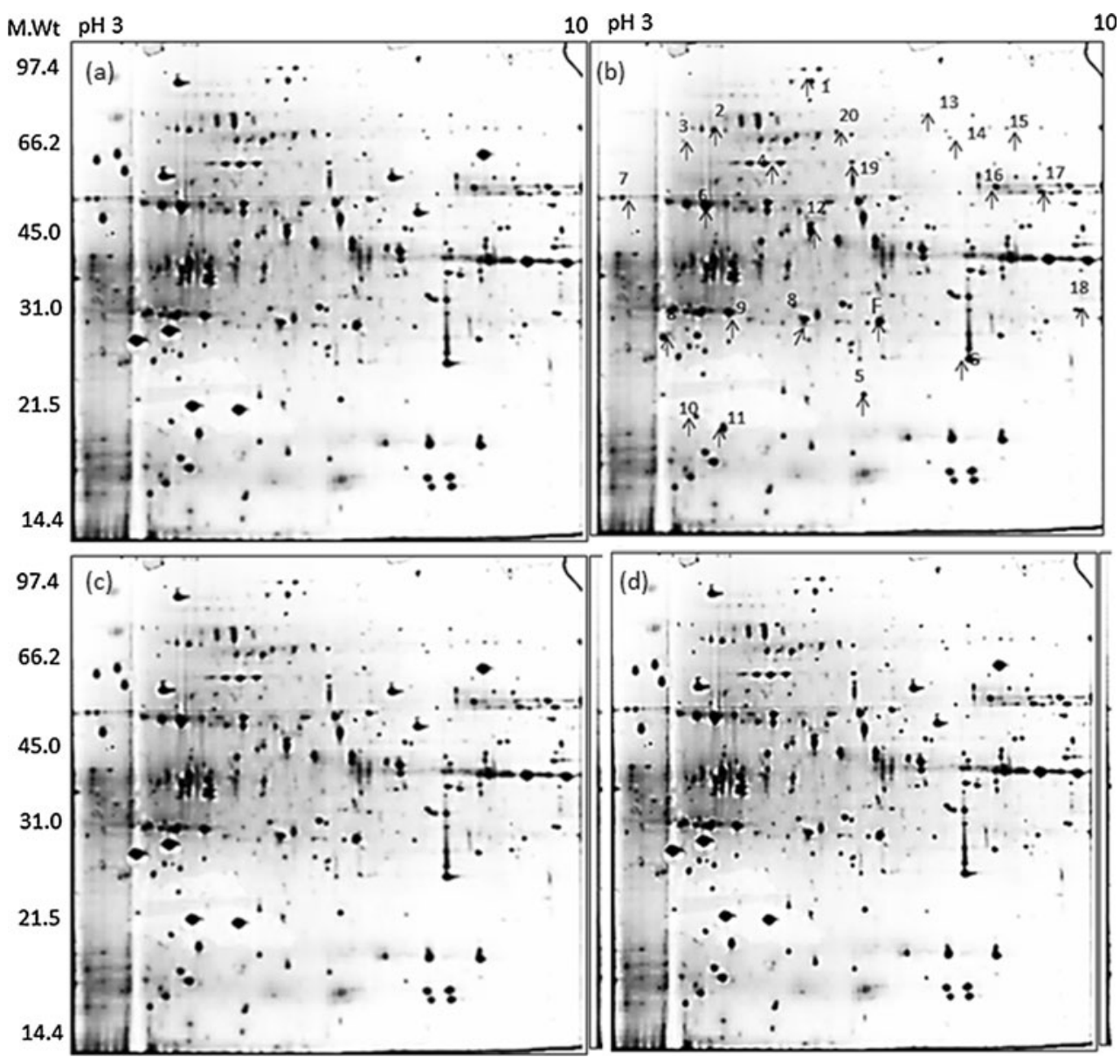

Table 2 Identification of differentially expressed proteins in root-nodules of Vigna radiata analyzed by LC/MSMS

\begin{tabular}{|c|c|c|c|c|c|c|c|c|}
\hline Spot & Accession number & Homology & $\%$ Coverage & $\begin{array}{l}\text { Matched } \\
\text { peptides }\end{array}$ & $\begin{array}{l}\text { Mascot } \\
\text { score }\end{array}$ & Mr value & PI value & Species \\
\hline $\mathrm{F}$ & $\mathrm{gi} / 22090$ & $\begin{array}{l}\text { HMW glutenin sub-unit } \\
\text { 1By9 }\end{array}$ & 20 & 19 & 55 & 76,055 & 8.64 & Triticum aestivum \\
\hline G & gi/53792564 & Hypothetical protein & 37 & 10 & 47 & 19,293 & 10.39 & Oryza sativa \\
\hline 8 & gi/6911142 & $\begin{array}{l}\text { Putative rich RNA } \\
\text { binding protein }\end{array}$ & 28 & 15 & 55 & 14,268 & 8.71 & Catharanthus roseus \\
\hline 9 & gi/6911144 & $\begin{array}{l}\text { Putative rich RNA } \\
\text { binding protein }\end{array}$ & 28 & 15 & 43 & 14,268 & 8.71 & Catharanthus roseus \\
\hline 5 & gi/255638833 & Unknown protein & 30 & 12 & 65 & 1,393 & 5.8 & Glycine max \\
\hline 12 & gi/6911144 & $\begin{array}{l}\text { Putative rich RNA } \\
\text { binding protein }\end{array}$ & 30 & 15 & 55 & 14,268 & 8.71 & Catharanthus roseus \\
\hline 13 & gi/205830697 & Hypothetical protein & 27 & 12 & 108 & 1,393 & 5.8 & Vitis royundifolia \\
\hline 14 & gi/205830697 & RNA Binding & 26 & 12 & 85 & 1,393 & 5.8 & Pseudotsuga menziesi \\
\hline 16 & gi/53792564 & Unknown protein & 27 & 10 & 46 & 19,293 & 10.39 & Oryza sativa \\
\hline 17 & $\mathrm{gi} / 5031275$ & Unknown protein & 29 & 15 & 58 & 21,722 & 5.8 & Prunus armeniaca \\
\hline 20 & gi/6911142 & $\begin{array}{l}\text { Putative rich RNA } \\
\text { binding protein }\end{array}$ & 30 & 15 & 46 & 14,268 & 8.71 & Catharanthus roseus \\
\hline
\end{tabular}

less effect was observed in non-exposed cadmium with $\mathrm{Fe}$ deficiency $(-\mathrm{Fe} /-\mathrm{Cd})$. Several reviews have been published on different aspects of ascorbate and glutathione, ranging from their biosynthesis (Smirnoff et al. 2001; Potters et al. 2002), their roles in transport system (Horemans et al. 2000) and stress defense (Noctor and Foyer 


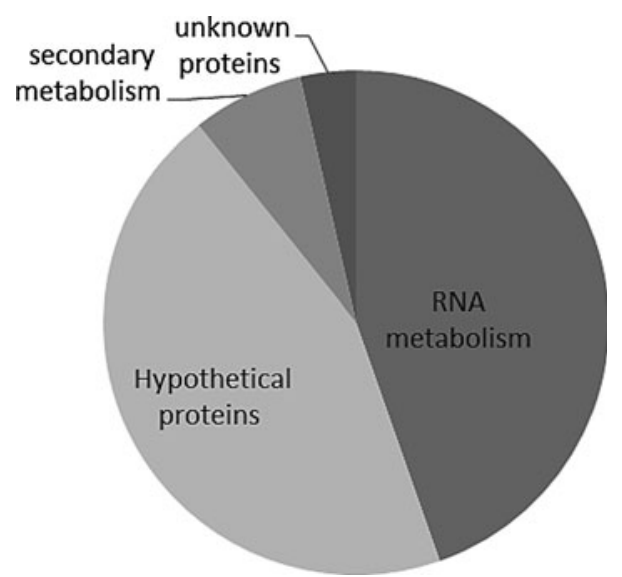

Fig. 7 Functional classification of identified proteins from rootnodules analyzed by LC/MS-MS using Map Man ontology as described by Beven et al. (1998)

Table 3 Linear correlation among the descriptive parameters with $\mathrm{Fe}$ and $\mathrm{Cd}$, values were normalized between the values measured in $\mathrm{Fe} / \mathrm{Cd}$ treated plants

\begin{tabular}{lll}
\hline & $\mathrm{Fe}$ & $\mathrm{Cd}$ \\
\hline Soluble protein & $\mathrm{r}=0.81^{* * *}$ & $\mathrm{r}=-0.475^{*}$ \\
Total ascorbate & $\mathrm{r}=0.518^{*}$ & $\mathrm{r}=0.601^{*}$ \\
Total glutathione & $\mathrm{r}=0.372$ & $\mathrm{r}=0.556^{*}$ \\
Leghemoglobin & $\mathrm{r}=0.900^{* * *}$ & $\mathrm{r}=-0.575^{*}$ \\
Ferritin content & $\mathrm{r}=0.873^{* * *}$ & $\mathrm{r}=-0.556^{*}$ \\
APX & $\mathrm{r}=0.672^{* *}$ & $\mathrm{r}=-0.549^{*}$ \\
SOD & $\mathrm{r}=0.699^{*}$ & $\mathrm{r}=-0.472^{*}$ \\
GR & $\mathrm{r}=0.6755^{* *}$ & $\mathrm{r}=0.722^{* *}$ \\
CAT & $\mathrm{r}=0.72 * *$ & $\mathrm{r}=-0.687 * *$ \\
\hline
\end{tabular}

The correlation coefficient $(\mathrm{r})$ and significant differences are given; $* P \leq 0.05$, ** $P \leq 0.01$, *** $P \leq 0.001$

1998) in plants. It has been generally established that glutathione and ascorbate play a prominent role in nonenzymatic mechanism to prevent oxidation of cellular compounds (Noctor and Foyer 1998) and involve in the induction of enzymes and gene expression (Alscher et al. 1987). In this study, the responses of glutathione and ascorbate to $\mathrm{Cd} / \mathrm{Fe}$ combined treatment were well consistent with those of antioxidative enzymes. Indeed, APX, $\mathrm{SOD}$, CAT, and GR activity in $+\mathrm{Fe} /+\mathrm{Cd}$ plants significantly increased compared to controls (Fig. 4). In white clover, ascorbate-glutathione pathway was highly induced with high activation of APX without visible injury or lipid peroxidation during the early period of drought stress (Lee et al. 2007). Similarly, the water deficit-induced activation of SOD and CAT increased during the first 14 days (Lee et al. 2009). In particular, the increase in SOD activity was high during this period. This activation of SOD might be associated with it having an effective role in protection against water-deficit induced oxidative stress. Foyer and Noctor (2000), for instance, concluded that as SOD catalyzes the dismutation of superoxide radicals to $\mathrm{H}_{2} \mathrm{O}_{2}$ and $\mathrm{O}_{2}$, it is perhaps the most important enzyme in cellular defense because it directly modulates the amounts of $\mathrm{O}_{2}{ }^{-}$and $\mathrm{H}_{2} \mathrm{O}_{2}$. Similarly it has been shown that salt stress induces an increase in SOD activity, and this has been frequently correlated with salt tolerance (Sreenivasulu et al. 2000; Sudhakar et al. 2001). A high activation of CAT in $+\mathrm{Fe} /+\mathrm{Cd}$ plants (Fig. $4 \mathrm{c}$ ) reflects that the $\mathrm{H}_{2} \mathrm{O}_{2}$ produced by SOD would in turn be scavenged mostly by CAT. The elevated activity of GR observed in $-\mathrm{Fe} /-\mathrm{Cd}$ and more severe in $+\mathrm{Fe} / \mathrm{Cd}$ plants may be also ascribable to the increased demand for reduced glutathione as a result of increased activity glutathione peroxidase. Glutathione is involved as a substrate for glutathione peroxidase and is therefore necessary for the removal of lipid peroxidases because GR reduces the oxidized glutathione which is generated by glutathione peroxidase (Potters et al. 2002; Ali et al. 2005). The observed increase in glutathione and ascorbate in $+\mathrm{Fe} / \mathrm{Cd}$ plants without change $(24 \mathrm{~h})$ or slight decrease $(72 \mathrm{~h})$ in lipid peroxidation level compared to controls suggested that the plants were still under mild intensity of stress so that they were capable to increase substrates and enzymes activity associated with ROS scavenging pathways.

In contrast, $\mathrm{Cd}$ exposure under $\mathrm{Fe}$-deficient condition ($\mathrm{Fe} /+\mathrm{Cd}$ ) significantly decreased glutathione and ascorbate concentration (Fig. 3b, c) along with the decrease in APX, SOD, CAT and GR activity (Fig. 4) with a concomitant increase of lipid peroxidation. However, in non-exposed cadmium along with $\mathrm{Fe}$-deficiency $(-\mathrm{Fe} /-\mathrm{Cd})$ the effect was less as compared to $-\mathrm{Fe} /+\mathrm{Cd}$ plants which indicates $\mathrm{Fe}$ is essential for alleviating toxic effects of cadmium.

Cd-exposure under Fe-deficient condition enhanced the intensity of oxidative stress as evidence given by twofold higher level of lipid peroxidation compared to control (Fig. 3a). It could be suggested that Cd-exposure under Fedeficient condition resulted in an over production of ROS which lead to oxidative injury such as membrane lipid peroxidation, protein oxidation, enzyme inhibition and DNA and RNA damage (Qadir et al. 2004) because Fe is important for expression of proteins which lead to conversion of singlet oxygen into hydrogen peroxide and finally into water (Qureshi et al. 2010).

In $-\mathrm{Fe} /+\mathrm{Cd}$ plants, the severe reduction in ascorbate and glutathione (Fig. 3b, c) might be due to glutathione depletion which in turn leads to a subsequent reduction in the ascorbate-glutathione cycle (Gomes-Júnior et al. 2006) and least effect was observed in $-\mathrm{Fe} /-\mathrm{Cd}$ plants. Indeed, the decrease in the activity of APX and GR, antioxidative enzymes using glutathione and ascorbate as substrate, was 
more prominent compared with that of SOD and CAT (Fig. 4). It has been well known that CAT and APX are important enzymes in root nodules and susceptible to $\mathrm{Fe}$ because they are heme containing enzymes (Deakin and Broughton 2009). At $72 \mathrm{~h}$ after Cd-exposure, the activity of APX and CAT in $-\mathrm{Fe} /+\mathrm{Cd}$ plants decreased by 64 and $30 \%$, respectively, compared to controls (Fig. 4a, c) and less affect was observed in $-\mathrm{Fe} /-\mathrm{Cd}$ plants. These decreases in APX and CAT activity well indicate that the plants failed to meet the demand of $\mathrm{Fe}$ for the formation of heme group and also a non-heme iron atom. Similarly, the water deficit-induced activation of SOD, CAT and APX failed to increase or in some cases slightly decreased during injurious period of drought stress (Lee et al. 2009). Thus SOD-CAT-APX antioxidant system in severe stress intensity might not be effective in scavenging ROS generated by stress. Indeed, the present data clearly indicated that $-\mathrm{Fe} /+\mathrm{Cd}$ plants suffered more severe intensity of oxidative stress compared with $-\mathrm{Fe} /-\mathrm{Cd}$ and $+\mathrm{Fe} /+\mathrm{Cd}$ ones so that they failed to retain non-enzymatic and enzymatic mechanism to prevent harmful effects of ROS on membrane integrity and growth. Taken together, it could be concluded that $\mathrm{Fe}$ efficiently alleviates Cd-induced oxidative damage by the enhancement of antioxidant substrates (Fig. 3b, c) and antioxidative enzymes activity compared to control (Fig. 4).

This endurance to $\mathrm{Cd}$ toxic impact under Fe-sufficient condition might be explicated by a role of $\mathrm{Fe}$ in terms of fulfilling the requirements of iron a metal ligand for antioxidant enzymes as well as serving as binding force between proteins to form multi-protein complexes. Indeed, $\mathrm{Cd}$ exposure resulted in a reduction of protein concentration in root nodules. The negative effect of $\mathrm{Cd}$-exposure was much less in Fe-sufficient than that in Fe-deficient condition (Fig. 2a). This might be due to the induction of specific metal binding proteins called metallothioneins and phytochelatins which mitigate the $\mathrm{Cd}$ stress involving sulforhydral groups (Benavides et al. 2005). Further, Cd-exposure resulted in significant decrease in leghemoglobin and ferritin concentration in nodules (Fig. 2b, c). This suggests that $\mathrm{Cd}$ exposure causes breakdown of bacterial proteins and flavonoids which help the root hairs in curling and formation of nodules (Balestrasse et al. 2004). Fe-deficiency has often resulted in reduction of nodulation and low formation of active nitrogenase, since nodules contain nitrogenase which requires Fe-Mo. It has been well documented that leghemoglobin is involved in $\mathrm{N}_{2}$-fixation in root nodules (Qureshi et al. 2010; Balestrasse et al. 2004). The oxygenated form of leghemoglobin can undergo slow autoxidation to the ferric form (metLb) giving rise to superoxide radicals and hence $\mathrm{H}_{2} \mathrm{O}_{2}$ by dismutation of singlet oxygen (Lodwig et al. 2003). Thus, Cd-induced oxidative stress severely restricts the activity of nitrogen fixing organs, since leghemoglobin is most important protein for the formation of nod genes (nif) (Balestrasse et al. 2004). Under drought conditions the content of leghemoglobin has been partially declined in alfalfa nodules (Van der Mark et al. 1981). These may be due to adverse effect on bacteriods which provides energy to nodules for nitrogen fixation. The reduction of leghemoglobin caused by Cd-exposure under Fe-deficient was remarkably recovered under Fe-sufficient condition (Fig. 2b). Furthermore, Cd-exposure decreased ferritin concentration in nodules much more severely under Fe-deficient $(-92 \%$ compared to control) than under Fe-sufficient condition (-33\%) (Fig. 2c) and $-\mathrm{Fe} /-\mathrm{Cd}$ conditions. This suggested that $\mathrm{Fe}-$ deficiency aggravates $\mathrm{Cd}$-induced breakdown of ferritin subunits. It has been well documented that ferritin involves in storage of Fe and protection of cells (Vincent et al. 2007). The results clearly indicate that $\mathrm{Fe}$ has a potential role in alleviating the negative effects of Cd-exposure on the formation, vitality and function of nodules by protecting the cells against ROS. The correlation curves between $\mathrm{Fe} / \mathrm{Cd}$ and other related parameters (Table 3 ) assessed showed that Fe is important for physiological processes and proves that $\mathrm{Fe}$ plays an important role in mitigating Cd stress as r values in case of correlation between Fe with soluble protein, leghemoglobin and ferritin content were $(P \leq 0.001)$, whereas, $(P \leq 0.01)$ in terms of $\mathrm{Cd}$-concentration. Indeed microscopic investigation of root nodules revealed that Cd-exposure altered the ultra-structure of root nodules (Fig. 5). In the plants under $\mathrm{Fe}$-deficient condition $(-\mathrm{Fe} /+\mathrm{Cd})$, the number of bacteriods and cortical cell divisions was eventually ceased up (Fig. 5c) and distorted and ruptured shape of cell wall were observed (Fig. $5 \mathrm{~g}$ ). When compared with $-\mathrm{Fe} /+\mathrm{Cd}$ plants, bacteroid and cell numbers relatively increased in $\mathrm{Fe}$ sufficient plants $(+\mathrm{Fe} /+\mathrm{Cd})(\mathrm{Fig} .5 \mathrm{~b})$ and deformation of cell wall remarkably alleviated even though distorted parts were still observed (Fig. 5f) and $-\mathrm{Fe} /-\mathrm{Cd}$ plants (Fig. 5d, h). These suggested that Fe plays an efficient role in growth and development of root-nodules by protecting physical structure against $\mathrm{Cd}$-toxic impact and in mitigating the alteration of nodulated genes (nod and nif) (Balestrasse et al. 2004) which are responsible for the formation of symbiosomes.

Recent advances in proteomic technologies provide the ability to discern sites of in vivo protein phosphorylation events in plant tissue in a high throughput manner by utilizing decision tree-driven tandem MS (Swaney et al. 2008). Several studies have been made on the root nodules of leguminous plants as a model plant Medicago trancatula (Larrainzar et al. 2007) and other species under different abiotic stress to identify the actual mechanism of hostpathogen relationship in which stress-responsive proteins are involved. Among twenty differentially proteins, eleven proteins responsive to combined $\mathrm{Fe} /+\mathrm{Cd}$ impact were 
identified (Table 2). Large number of unknown and hypothetical proteins has been often reported in the root nodules under abiotic stress (Usadel et al. 2005; Thimm et al. 2004). Our study surprisingly also observed number of some unknown and hypothetical proteins (Table 2), although the reason remains unclear. This could be due to the fact that in root nodules most of the high abundant and detectable proteins have been characterized to be suitable for physiological processes. Furthermore, our proteomic analysis of root nodules identified the proteins involving in RNA metabolism and storage of grains for long shelf as classified and described by Beven et al. (1998). Despite the evidence that rootnodule proteins were differentially expressed by the level of $\mathrm{Fe}$ under $\mathrm{Cd}$-stressed condition, further trascriptomic works and metabolites profiling in the nodule organelles such as mitochondria, plastids, peroxisomes will be required since the proteomic analysis revealed abundant number of hypothetical and unknown proteins.

Acknowledgments This study has been supported by UGC (University grants commission) and DST (Department of Science and Technology), Govt. of India.

Open Access This article is distributed under the terms of the Creative Commons Attribution License which permits any use, distribution, and reproduction in any medium, provided the original author(s) and the source are credited.

\section{References}

Aebi H (1984) Catalase in vitro. Methods Enzymol 105:121-126

Ali MB, Hahn EJ, Paek KY (2005) Effects of temperature on oxidative stress defense systems, lipid peroxidation and lipoxygenase activity in Phalaenopsis. Plant Physiol Biochem 43:213-223

Alscher R, Bower J, Zipfel W (1987) The basis for different sensitivities of photosynthesis to $\mathrm{SO}_{2}$ in two cultivars of pea. J Exp Bot 38:99-108

Alvarez S, Berla BM, Sheffield J, Cahoon RE, Jez JM, Hicks LM (2009) Comprehensive analysis of the Brassica juncea root proteome in response to cadmium exposure by complementary proteomic approaches. Proteomics 9:2419-2431

Anderson ME (1985) Determination of glutathione and glutathione disulfide in biological samples. Methods Enzymol 113:555-570

Aronon JD, Israelstam GF (1979) Copper enzymes in isolated chloroplast oxidase in Beta vulgaris. Plant Physiol 42:287-292

Astolfi S, Zuchi S, Neumann G, Cesco S, Sanita di Toppi L, Pinton R (2012) Response of barley plants to Fe deficiency and $\mathrm{Cd}$ contamination as affected by $\mathrm{S}$ starvation $\mathrm{J}$ Exp Bot. doi: $10.1093 / \mathrm{jxb} / \mathrm{err} 344$

Balestrasse KB, Gardey L, Galleego SM, Tomaro ML (2004) Response of antioxidant defense system in soybean nodules and roots subjected to cadmium stress. Aust J Plant Physiol 28:497-504

Benavides MP, Susana MG, Tomaro ML (2005) Cadmium toxicity in plants. Braz J Plant Physiol 17(1):21-34

Beven M et al (1998) Analysis of $1.9 \mathrm{Mb}$ contiguous sequence from chromosome 4 of Arabidopsis thaliana. Nature 391:485-493
Clement JC, Shrestha J, Ehrenfeld JG, Jaffe PR (2005) Ammonium oxidation coupled to dissimilatory reduction of iron under anaerobic conditions in wetland soils. Soil Biol Biochem 33: 2323-2328

Deakin WJ, Broughton WJ (2009) Symbiotic use of pathogen strategies: rhizobial protein secretion. Nature Rev Biol 7:312-320

Dhindsa RH, Plumb-Dhindsa P, Thorpe TA (1981) Leaf senescence correlated with increased level of membrane permeability, lipid peroxidation and decreased level of SOD and CAT. J Exp Bot 32:93-101

Fagioni MD, Amici GM, Timperio AM, Zolla L (2009) Proteomic analysis of multi protein complexes in the thylakoid membrane upon cadmium treatment. J Proteome Res 8:310-326

Foyer CH, Noctor G (2000) Oxygen processing in photosynthesis: regulation and signaling. New Phytol 146:359-388

Gomes-Júnior RA, Moldes CA, Delite FS, Pompeu GB, Gratão PL, Mazzafera P, Lea PJ, Azevedo RA (2006) Antioxidant metabolism of coffee cell suspension cultures in response to cadmium. Chemosphere 65:1330-1337

Halliwell B, Gutteridge JMC (1999) Free radicals in biology and medicine, 3rd edn. Oxford University Press, New York

Heath RL, Packer L (1968) Photoperoxidation in isolated chloroplast I. Kinetics and stoichiometry of fatty acid peroxidation. Arch Biochem Biophys 125:189-198

Hiscox JD, Israclstam GF (1979) A method for interaction of chlorophyll from leaf tissue without maceration. Can J Bot 57:1332-1334

Horemans N, Foyer CH, Potters G, Asard H (2000) Ascorbate functions and associated transport systems in plants. Plant Physiol Biochem 38:531-540

Krouma A, Drevon JJ, Abdelly C (2006) Genotypic variation of nitrogen fixing common bean (Phaseolus vulgaris L.) in response to iron deficiency. J Plant Physiol 163:1049-1100

La Rue TA, Child JJ (1979) Sensitive flurometric assay for leghemoglobin. Ann Biochem 92:11-15

Larrainzar E, Wienkoop S, Weckwerth W, Ladrera R, Arrese-Igor C, González EM (2007) Medicago truncatula root nodule proteome analysis reveals differential plant and bacteroid responses to drought stress. Plant Physiol 144:1495-1507

Law MY, Charles SA, Halliwell B (1983) Glutathione and ascorbic acid in spinach leaves (Spinacia oleracea) chloroplasts: the effect of hydrogen peroxide and of paraquat. Biochem $\mathrm{J}$ 210(899):903

Lee BR, Kim KY, Jung WJ, Avice JC, Ourry A, Kim TH (2007) Peroxidases and lignification in relation to the intensity of water deficit stress in white clover (Trifolium repens L.). J Exp Bot 58:1271-1279

Lee BR, Jung WJ, Jin YL, Avice JC, Ourry A, Kim TH (2009) Water deficit-induced oxidative stress and the activation of antioxidative enzymes in white clover leaves. Biol Plant 53:505-510

Lodwig EM, Hosie AHF, Bourdès A, Findlay K, Allaway D, Karunakaran R, Downie JA, Poole PS (2003) Amino-acid cycling drives nitrogen fixation in the legume-rhizobium symbiosis. Nature 422:722-726

Maroco JP, Rodrigues ML, Lopes C, Chaves MM (2002) Limitations to photosynthesis in grapevine under drought-metabolic and modelling approaches. Funct Plant Physiol 29:1-9

Molloy MP, Herbert BR, Walsh BJ, Tyler MI, Traini M (1998) Extraction of membrane proteins by differential solubilization for separation using two dimensional gel electrophoresis. Electrophoresis 19:837-844

Muneer S, Ahmad J, Bashir H, Moiz S, Qureshi MI (2011) Studies to reveal importance of $\mathrm{Fe}$ for $\mathrm{Cd}$ tolerance in Brassica juncea. Int J Appl Biotech Biochem 1(3):321-338 
Nakano M, Nobuta K, Vemaraju K, Tej SS, Skogen JW, Meyers BC (2006) Plant MPSS databases: signature-based transcriptional resources for analyses of mRNA and small RNA. Nucleic Acids Res 34:731-735

Noctor G, Foyer CH (1998) Ascorbate and glutathione: keeping active oxygen under control. Ann Rev Plant Physiol Plant Mol Biol 49:249-279

O' Hara GW, Boonkerd N, Dilworth MJ (1998) Mineral constraints to nitrogen fixation. Plant Soil 108:98-110

Pinto AP, Mota AM, de varennes A, Pinto FC (2004) Influence of organic matter on the uptake of cadmium, zinc, copper and iron by sorghum plants. Plant Sci Total Environ. 326:239-247

Potters G, De Gara L, Assad H, Horemans (2002) Ascorbate and glutathione: guardians of the cell cycle, partners in crime? Plant Physiol Biochem 40:537-548

Qadir S, Qureshi MI, Javed S, Abdin MZ (2004) Genotypic variation in phytoremediation potential of Brassica juncea cultivars exposed to Cd-stress. Plant Sci 167:1171-1181

Qureshi MI, Amici GMD, Fagioni M, Rinalducci S, Zolla L (2010) Iron stabilizes thylakoid protein-pigment complexes in Indian mustard during Cd-phytoremediation as revealed by BN-SDSPAGE and ESI-MS/MS. J Plant Physiol 167:761-770

Ragland M, Theil EC (1993) Ferritin (mRNA, protein) and iron concentrations during soybean nodule development. Plant Mol Biol 21:55-560

Rao MV (1992) Cellular detoxification mechanisms to determine age dependent injury in tropical plant exposed to SO2. J Plant Physiol 140:733-740

Roskams AJI, Connors JR (1994) Iron, transferring and ferritin in the rats brain during development and aging. J Neurochem 63: 709-716

Roth UE, Von RP, Clemens S (2006) Proteome changes in Arabidopsis thaliana roots upon exposure to Cd. J Exp Bot 57:4003-4013

Sanita di Toppi L, Gabbrielli R (1999) Response to cadmium in higher plants. Environ Exp Bot 4:105-130

Sárvári É, Fodor F, Cseh E, Varga A, Záray GY, Zolla L (1999) Relationship between changes in ion content of leaves and chlorophyll-protein composition in cucumber under $\mathrm{Cd}$ and $\mathrm{Pb}$ stress. Z Naturforsch 54c:746-753
Siedlecka A, Krupa Z (1999) Cd/Fe interaction in higher plants-its consequences for the photosynthetic apparatus. Photosynthetica 36:321-331

Smirnoff N, Conklin PL, Loewus FA (2001) Biosynthesis of ascorbic acid in plants: a renaissance. Ann Rev Plant Physiol Plant Mol Biol 52:437

Sreenivasulu N, Grimm B, Wobus U, Weschke W (2000) Differential response of antioxidant compounds to salinity stress in salttolerant and salt sensitive seedlings of foxtail millet (Setaria italica) Physiol. Plant 109:435-442

Sudhakar C, Lakshmi A, Giridara Kumar A (2001) Changes in the antioxidant enzyme efficacy in two high yielding genotypes of mulberry (Morus alba L.) under $\mathrm{NaCl}$ salinity. Plant Sci 161:613-619

Swaney DL, McAlister GC, Coon JJ (2008) Decision tree-driven tandem mass spectrometry for shotgun proteomics. Nature 5:959-964

Tang C, Robson AD, Dilworth MJ (1991) The role of iron in nodulation and nitrogen fixation in Lupin anustifolius $L$. is sensitive to iron deficiency. New Phytol 117:243-250

Thimm O, Blasing O, Gibon Y, Nagel A, Meyer S, Kruger P, Selbig J, Muller LA, Rhee SY, Stitt M (2004) MAPMAN: a user-driven tool to display genomics data sets onto diagrams of metabolic pathways and other biological processes. Plant J 37:914-939

Usadel B, Nagel A, Thimm O, Redestig H, Blaesing OE, PalaciosRojas N, Selbig J, Hannemann J, Piques MC, Steinhauser D et al (2005) Extension of the visualization tool MapMan to allow statistical analysis of arrays, display of corresponding genes, and comparison with known responses. Plant Physiol 138:1195-1204

Van der Mark F, de Lange T, Bienfait HF (1981) The role of ferritin in developing primary bean leaves under various light conditions. Planta 153:338-342

Vanoni MA, Curti B (2005) Structure-function studies on the iron sulfur flavoenzymes glutamate synthetase: an unexpectedly complex self-regulated enzyme. Arch Biochem. Biophy. 433:193-211

Vincent D, Ergul A, Bohlman MC, Tattersall EA, Tillet RL, Wheatley MD (2007) Proteomic analysis reveals differences between Vitis venifera L. cv. Chardonnay and CV. Cabernet sauvignon and their response to water deficit and salinity. J Exp Bot 5B:1873-1893 